Silke Conrad • Hans-Martin Kauffmann • Ken-ichi Ito

Roger G. Deeley • Susan P.C. Cole • Dieter Schrenk

\title{
Identification of human multidrug resistance protein 1 (MRP1) mutations and characterization of a G671V substitution
}

Received: July 16, 2001 / Accepted: August 21, 2001

\begin{abstract}
The multidrug resistance protein 1 (MRP1) belonging to the ATP-binding cassette (ABC) superfamily of transport proteins can confer resistance to multiple natural product drugs and methotrexate in human tumor cells. In addition, MRP1 is expressed in normal tissues acting as an efflux pump for glutathione, glucuronate, and sulfate conjugates and may thus influence the pharmacokinetic properties of many drugs. Using polymerase chain reaction-single-strand conformation polymorphism analysis, we screened 36 Caucasian volunteers for mutations in the coding exons of the MRP1 gene, including the adjacent intron sequences. Among several mutations found, two are expected to cause amino acid substitutions. One of these mutations $(\mathrm{G} 671 \mathrm{~V})$ was of special interest because it is located near the first nucleotide binding domain. To determine whether this mutation caused a change in the MRP1 phenotype, a mutant MRP1 expression vector was constructed and transfected into SV40-transformed human embryonic kidney cells (HEKSV293T) and the transport properties of the mutant protein were examined. Transport of the MRP1 substrates leukotriene $C_{4}, 17 \beta$-estradiol 17 $\beta$-(D)glucuronide, and estrone sulfate by membrane vesicles prepared from transiently transfected HEKSV293T cells was comparable to that of wild-type MRP1.
\end{abstract}

Key words Human MRP1 · Genetic variations · Expression analysis $\cdot$ Membrane vesicles $\cdot$ Transport assays $\cdot$ Drug conjugate transport

S. Conrad · H.-M. Kauffmann · D. Schrenk $(\bowtie)$

Food Chemistry \& Environmental Toxicology, University of Kaiserslautern, Erwin-Schroedinger-Str. 52, D-67663 Kaiserslautern, Germany

Tel. +49-631-2053043; Fax +49-631-2054398

e-mail: schrenk@rhrk.uni-kl.de

K. Ito $\cdot$ R.G. Deeley $\cdot$ S.P.C. Cole

Cancer Research Laboratories, Queen's University, Kingston,

Ontario, Canada

\section{Introduction}

The human multidrug resistance protein 1 (MRP1) cDNA was originally cloned from a drug-selected lung cancer cell line resistant to multiple chemotherapeutic agents. It encodes a $190-\mathrm{kDa}$ polytopic transmembrane protein comprising 1531 amino acids and belongs to subfamily $\mathrm{C}$ of the superfamily of ATP-binding cassette (ABC)-transporters (Cole et al. 1992; Hipfner et al. 1999a; Hopper et al. 2001; Kuwano et al. 1999). MRP1 acts as a cellular efflux pump for numerous endogenous and exogenous glutathione (GSH)-, glucuronate-, and sulfate-conjugated organic anions (Jedlitschky et al. 1996). The GSH-conjugated arachidonic acid derivative leukotriene $\mathrm{C}_{4}\left(\mathrm{LTC}_{4}\right)$ and the glucuronidated estrogen $17 \beta$-estradiol $17 \beta$-(D)-glucuronide $\left(\mathrm{E}_{2} 17 \beta \mathrm{G}\right)$ are two of the best characterized substrates of MRP1 (König et al. 1999; Mao et al. 2000). Other potential endogenous transport substrates include glutathione disulfide (GSSG), estrone sulfate, GSH-conjugates of prostaglandin A2 (Evers et al. 1997; Leier et al. 1994, 1996; Qian et al. 2001), and 4-hydroxynonenal (Renes et al. 2000).

In tumor cells, MRP1 is able to confer resistance against a variety of natural product drugs, such as anthracyclines, vinca alkaloids, and VP-16 (Cole et al. 1994; Zaman et al. 1994), and this resistance is associated with a reduced intracellular drug accumulation. Multidrug resistance mediated by MRP1 and certain other ABC-transporters represents a serious limitation to cancer chemotherapy. Physiologically, MRP1, which is expressed in most organs, is proposed to contribute to the cellular antioxidative defense system. By actively extruding GSSG from cells, it may help to maintain intracellular GSH/GSSG balance after exposure to oxidative stress. Furthermore, it is thought to be involved in inflammatory reactions because mrp1 (-/-) knockout mice show an impaired response to inflammatory stimuli, consistent with the reduced rates of $\mathrm{LTC}_{4}$ transport observed in cells lacking mrp1 (Wijnholds et al. 1997).

Hence, mutations affecting MRP1 expression and/or MRP1 transport activity can be expected to influence the pharmacokinetic properties of chemotherapeutic drugs and consequently their desired and adverse effects. Further- 
more, such mutations in MRP1 that downregulate its transport activities could impair the antioxidative defense system and antiinflammatory responses after exposure of cells to certain stimuli such as certain xenobiotics with prooxidant activity. Consequently, knowledge of such an unfavorable genotype may help to develop interventions to prevent undesired drug actions.

In the present study, we screened 36 Caucasian volunteers for mutations in the MRP1 gene by investigating the coding exons 2-31 with their adjacent intron sequences. We identified a variety of mutations and measured the $M R P 1$ mRNA levels in lymphocytes to determine which, if any, mutations were associated with changes in expression levels.

One mutation identified causes the substitution of a highly conserved glycine residue to valine and is located only six amino acids upstream from the Walker A signature motif of the first nucleotide binding domain of the protein. Consequently, we recreated this mutation in a MRP1 mammalian expression vector and analyzed its transport properties when it was expressed in human embryonic kidney cells (HEKSV293T).

\section{Materials and methods}

\section{Study population}

Blood samples from 36 healthy Caucasian volunteers (17 female and 19 male) born between 1964 and 1977 were analyzed in this study. Participants gave their written informed consent prior to their inclusion in the study. The study design was approved by the Ethics Commission of the Landesärztekammer Rheinland-Pfalz.

RNA preparation and reverse transcriptase-polymerase chain reaction

Total RNA was extracted from tissues with a phenolchloroform extraction method (Chomczynski and Sacchi 1987) and from peripheral lymphocytes using the RNeasy Mini kit (Qiagen, Hilden, Germany) according to the manufacturer's protocol. Reverse transcription was performed in a $10-\mu l$ assay and multiplex polymerase chain reaction (PCR) in a $25-\mu l$ assay using 35 cycles as previously described (Kauffmann et al. 1998). The following primers were used: MRP1: sense primer AAGACCAAGACGT ATCAGGT (bases 1456-1475 of the human MRP1 cDNA, EMBL GenBank accession number L05628), antisense primer CAATGGTCACGTAGACGGCAA (bases 17141694). As control, a glyceraldehyde-3-phosphate dehydrogenase $(G A P D H)$ fragment (Conrad et al. 2001) was amplified simultaneously.

\section{DNA preparation and PCR}

Genomic DNA from peripheral blood lymphocytes was prepared by use of a Blood \& Cell Culture kit (Qiagen).
The primer pairs used to amplify genomic DNA were designed based on the genomic sequence of $M R P 1$ reported in GenBank (Table 1). Primers were directed against intronic sequences located near the exon-intron boundaries, allowing amplification of the complete exons and of the splice donor and acceptor sites. PCR was performed using the same thermal profile as described above. The standard PCR reaction was carried out in a $25-\mu \mathrm{l}$ volume containing $100 \mathrm{ng}$ genomic DNA, $10 \mathrm{mM}$ TRIS, $50 \mathrm{mM} \mathrm{KCl}, 2.5 \mathrm{mM} \mathrm{MgCl}_{2}$, $0.2 \mathrm{mM}$ dNTPs, $4 \%$ dimethylsulphoxide (DMSO), $0.4 \mu \mathrm{M}$ of sense and anti-sense primers and 0.625U Taq DNA polymerase. As only a small part of the intronic sequences adjacent to exons 4 to 6 and 13 to 15 have been published, we performed reverse transcriptase (RT)-PCR as described above to amplify these exons.

Single-strand conformation polymorphism and sequence analyses

Five microliters of each PCR product was mixed with $7.5 \mu \mathrm{l}$ denaturing buffer $(92 \%$ formamide, $20 \mathrm{mM}$ ethylenediaminetetraacetate (EDTA), $20 \mathrm{mM} \mathrm{NaOH}$, $0.01 \%$ bromophenol blue, $0.01 \%$ xylene cyanol) and heated to $97^{\circ} \mathrm{C}$. After $10 \mathrm{~min}$, the samples were chilled on ice for 2 min and subjected to electrophoresis on a $6 \%$ or $8 \%$ polyacrylamide gel. Gels were run with $1 \times$ tris-borate + EDTA (TBE) at $40 \mathrm{~mA}$ for $4-6 \mathrm{~h}$ at $4^{\circ} \mathrm{C}$, depending on the size of the PCR product. Bands were visualized by silver staining. When mobility shifts of a DNA fragment were detected, either direct sequencing of the PCR products was carried out or they were cloned into a pCRII vector using the TOPO TA cloning kit (Invitrogen, Leek, Netherlands). Plasmids were purified using the Wizard Plus Minipreps DNA purification system (Promega, Mannheim, Germany). Sequencing was performed with the Thermo Sequenase cycle sequencing kit (Amersham Pharmacia Biotech, Freiburg, Germany).

\section{Site-directed mutagenesis}

The mutation of Gly ${ }^{671}$ to Val was generated using the sense primer 5'P-CTCCATCCCCGAAGTGGCTTTGGTGGC CG-3' (substituted nucleotides are bold and underlined) with the U.S.E. mutagenesis kit (Amersham Pharmacia Biotech, Quebec, Canada), according to the manufacturer's instructions. As template for mutagenesis, a pGEM-3z (Promega, Madison, WI, USA) HindIII construct, containing nucleotides 1546-2875 of the coding sequence of MRP1, was used. The mutation was confirmed by diagnostic digestion and sequencing, and then a 0.6-kb EcoNI/Bsm BI fragment was subcloned into the MRP1 expression vector pcDNA3.1(-) (Invitrogen, Carlsbad, CA, USA)-MRP1 $1_{\mathrm{K}}$ (Ito et al. 2001a).

Transfections and immunoblotting

For transient transfections, empty vector, wild-type and mutant pcDNA3.1(-)-MRP1 $1_{\mathrm{K}}$ were transfected into 
Table 1. Primers used in this study for the amplification of individual exons in the multidrug resistance protein 1 (MRP1) gene

\begin{tabular}{|c|c|c|c|}
\hline Exon & Forward $\left(5^{\prime} \rightarrow 3^{\prime}\right)$ & Reverse $\left(5^{\prime} \rightarrow 3^{\prime}\right)$ & Size (bp) \\
\hline \multicolumn{4}{|l|}{$5^{\prime}$-flank. } \\
\hline 2 & TGACCCCTCGCCTGTGTTTG & CTTCССАССССССАСАACGA & 244 \\
\hline 3 & TCTGTTGTAGGATATGTATGTGC & CTTACGAGTTATTACTTTTGGTCTC & 233 \\
\hline $4-6^{\mathrm{b}}$ & CGCTGCTTGCTACCTTTTTAATTC & TCAACCCTGTGATCCACCAG & 333 \\
\hline 7 & СТCCTGTCATTGACTCTCATTGC & CATCCTGGATTGAGGCCACAG & 256 \\
\hline 8 & CTGTGGTAGGGGGCTGCATC & CTGAAAGATCAAAGCCAAGGAGGG & 351 \\
\hline 9 & CСCTGCCCCCACGTGTCACAA & AATCCCCACGCTGGCCCCAGA & 319 \\
\hline 10 & CCCACAGGCCCTGGTGATCA & GTTAAACACACACCAGCCACAGG & 182 \\
\hline 11 & TGTTTTCTTCTGTCTGGTGAGTG & TCATGGAGAGGCCTCTGCCTA & 201 \\
\hline 12 & ATAGCTGGTGATGTTGAGTG & CAATGAGGGCCAGGAAAAAT & 311 \\
\hline 13 & GGCACAGCAGTCAGCCACTG & CTGTACCTGCACGATGCTGC & 190 \\
\hline $13-15^{\mathrm{b}}$ & ACCTTCACCTGGGTCTGCAC & ATTCAGTGTGGGAGGGTCGCT & 339 \\
\hline 16 & TGAGCCAGGTGTGTTGTGTCGT & TCCCCGCTGGTCCTCATCCT & 176 \\
\hline 17 & CACCTCGTTCTCCATTTGCAACT & CGGCAACAGCTGACTGATTCAG & 250 \\
\hline 18 & AAGATTTCCCAGGAAACCCACTCCT & AGACGGCCCAACACCAAGCC & 250 \\
\hline 19 & GTGGCCGGGTGTCCCCTTTGC & GGCTGCCCCTACCGTTCTCCT & 223 \\
\hline 20 & CСССАСТTGCССССТTТGTCТC & GCCTTCCTCCCCGCCCTTAC & 144 \\
\hline 21 & CCTCCGACCCTGCCCAAGGCAT & CTATAAACTCCAGCCACTATCATCAC & 239 \\
\hline 22 & CTGGGTGCGTGCATGTGTGCTAAG & AAATCAGGCGGGGTGGGAGAC & 288 \\
\hline 23 & GGATCGCCGTGTTTGGCTAC & TGGACGAAGTAGATGAGGCC & 310 \\
\hline 24 & GCAGCCCGGCTCTAACATTTTGC & CTCCTCCACCCGCTCCTGCA & 366 \\
\hline 25 & GCTGTAAGCCAAGTCTCTGTAG & GGAATCCAAAGCCAAGGACAACT & 268 \\
\hline 26 & CGAAATGCCACGTGACTCTT & GGGTAAAGGTACACCAAAGAC & 183 \\
\hline 27 & GTCACAGCTTTACCAGATGGACTG & GGTGAGGGAATGGGGCGATG & 234 \\
\hline 28 & ACCACACCTGGGCCCTTCTGT & CTTGCCAGCTCTGGCTCACC & 231 \\
\hline 29 & TGACACAGGTGTCACATGCCGTC & TTCACCCCCGCCTACCTGAG & 226 \\
\hline 30 & TGACCCAACACTATCTCCTGGTT & CAGTGAGTAAGGCAAACTCCC & 286 \\
\hline 31 & АТССССТСТTСССТCAGGGT & GCCCTGCAGTTCTGACCAGAT & 163 \\
\hline
\end{tabular}

${ }^{a}$ Polymerase chain reation of the GC-rich 5'flanking region was performed with Clontech Advantage GC-Genomic Polymerase Mix (Clontech, Heidelberg, Germany)

${ }^{\mathrm{b}}$ Primers were used for reverse transcriptase-polymerase chain reaction (see Materials and methods)

HEKSV293T cells as described (Ito et al. 2001a). The cells were harvested $48 \mathrm{~h}$ after transfection, and inside-out membrane vesicles were prepared as described previously (Ito et al. 2001a; Loe et al. 1996a). The MRP1 protein levels were determined by immunoblot and/or dot blot analysis (Hipfner et al. 1999b; Ito et al. 2001a). Briefly, dot blots were prepared on Immobilon-P membrane (Millipore, Bedford, MA, USA) in a 96-well vacuum manifold (Millipore, Mississauga, Ontario, Canada) by blotting membrane vesicles in Tris-buffered saline (TBS) containing Tween 20 (TBS-T) and draining slowly by gravity. After washing the wells with TBS-T, the apparatus was disassembled and the blots were blocked for $0.5-1 \mathrm{~h}$ with $4 \%$ (w/ v) nonfat milk in TBS-T and probed with the MRP1-specific murine monoclonal antibody QCRL-1 (diluted 1:5000) for $2 \mathrm{~h}$ or overnight (Hipfner et al. 1996). The immunoreaction was visualized using a horseradish peroxidase-conjugated goat anti-mouse antibody (Pierce, Edmonton, Alberta, Canada) (diluted 1:10000), followed by chemiluminescence detection with the Renaissance chemiluminescence blotting technique (NEN Life Science Products, Boston, MA, USA). Immunoblotting was performed as described previously (Ito et al. 2001a).

Inside-out membrane vesicle transport studies

The ATP-dependent transport of $\left[{ }^{3} \mathrm{H}\right] \mathrm{LTC}_{4}$ (Amersham Pharmacia Biotech, Buckinghamshire, UK), $\left[{ }^{3} \mathrm{H}\right] \mathrm{E}_{2} 17 \beta \mathrm{G}$
(NEN Life Science Research Products) and $\left[{ }^{3} \mathrm{H}\right]$ estrone sulfate (Perkin-Elmer, Boston, MA, USA) into membrane vesicles was measured by rapid filtration (Ito et al. 2001a; Loe et al. 1996a, b; Qian et al. 2001). Briefly, transport assays were performed at $37^{\circ} \mathrm{C}$ for $\mathrm{E}_{2} 17 \beta \mathrm{G}$ and at $23^{\circ} \mathrm{C}$ for $\mathrm{LTC}_{4}$ in a $50-\mu$ l total-reaction volume containing $400 \mathrm{nM}$ $\mathrm{E}_{2} 17 \beta \mathrm{G}(120 \mathrm{nCi})$ or $50 \mathrm{nM} \mathrm{LTC} \mathrm{LT}_{4}(40 \mathrm{nCi}), 4 \mathrm{mM}$ AMP or ATP, $10 \mathrm{mM} \mathrm{MgCl}_{2}, 100 \mu \mathrm{g} / \mathrm{ml}$ creatine kinase, $10 \mathrm{mM}$ creatine phosphate, and $2 \mu \mathrm{g}$ of vesicle protein. Uptake was terminated at various time points by rapid dilution in ice-cold transport buffer and filtration under vacuum through glassfiber filters (Type A/E; Gelman Sciences, Dorval, Quebec, Canada) using a Hoeffer filtration manifold (Hoeffer Scientific Instruments, San Francisco, CA, USA). Filters were immediately washed twice and dried, and vesicleassociated radioactivity was quantified by scintillation counting. All data were corrected for the amount of $\left[{ }^{3} \mathrm{H}\right] \mathrm{E}_{2} 17 \beta \mathrm{G}$ or $\left[{ }^{3} \mathrm{H}\right] \mathrm{LTC}_{4}$, which remained bound to the filter in the absence of vesicle protein (usually less than $10 \%$ of the total radioactivity). All transport experiments were carried out in triplicate. The kinetic parameters of $\left[{ }^{3} \mathrm{H}\right] \mathrm{LTC}_{4}$ uptake were determined in the same reaction mixture as described above using $4 \mu \mathrm{g}$ of vesicle protein and various concentrations of $\left[{ }^{3} \mathrm{H}\right] \mathrm{LTC}_{4}$ at one selected time point, for which the $\mathrm{LTC}_{4}$ uptake was linear with each of the membrane preparations.

$\left[{ }^{3} \mathrm{H}\right]$ estrone sulfate uptake was performed at $37^{\circ} \mathrm{C}$ in a $50-\mu 1$ total-reaction volume containing $225 \mathrm{nM}$ estrone sul- 
fate $(100 \mathrm{nCi})$, in the presence and absence of $1 \mathrm{mM} \mathrm{GSH}$ and the same components described above. Membrane proteins were preincubated in $0.5 \mathrm{mM}$ acivicin for $10 \mathrm{~min}$ at $37^{\circ} \mathrm{C}$ prior to measuring $\left[{ }^{3} \mathrm{H}\right]$ estrone sulfate uptake.

\section{Results}

In the present study, the 30 coding exons of the MRP1 gene, including portions of the flanking intron sequences, were screened for mutations. In order to identify genetic variations, PCR-single-strand conformation polymorphism (SSCP) analysis of all fragments was carried out with DNA isolated from blood of 36 volunteers. The fragments showing variations by SSCP analysis were sequenced and compared with the published MRP1 sequences. As wild-type sequences we used GenBank accession numbers AC003026 and U91318, which included the complete genomic sequence from exon 12 to exon 31 and AF022824-AF022853 comprising exon 2 to exon 12 (Grant et al. 1997). The sequencing procedure resulted in the identification of several mutations, which are listed in Table 2.

Most of the mutations are located in intronic sequences close to the conserved $5^{\prime}$ donor (GT) sites (mutations in introns 11,12 , and 20), the $3^{\prime}$ acceptor (AG) sites (mutations in introns 26 and 30), or the branch site (introns 11 and 20). We identified several silent (wobble) mutations that do not alter the amino acid sequence. However, such mutations might affect RNA stability. Two mutations are predicted to cause an amino acid exchange. One rare het-

Table 2. Mutations in the $M R P 1$ gene and median mRNA expression levels of samples with different $M R P 1$ genotypes

\begin{tabular}{lllrr}
\hline Location & $\begin{array}{l}\text { Position } \\
\text { SNPs }\end{array}$ & Change & FRE & EXP $^{\mathrm{a}}$ \\
\hline Intron 7 & ${ }^{809+54} \mathrm{C} / \mathrm{A}$ & Intronic & 2.8 & 101 \\
Exon $8^{\mathrm{b}}$ & ${ }^{825} \mathrm{~T} / \mathrm{C}$ & Silent & 2.8 & 51 \\
Intron 8 & ${ }^{1040+13} \mathrm{~T} / \mathrm{C}$ & Intronic & 16.7 & 95 \\
Exon 10 & ${ }^{1299} \mathrm{G} / \mathrm{T}$ & Arg433Ser & 1.4 & 156 \\
Intron $11^{\mathrm{b}}$ & ${ }^{1474-48} \mathrm{C} / \mathrm{T}$ & Intronic & 2.8 & 146 \\
Intron 11 & ${ }^{1474-8} \mathrm{~T} / \mathrm{C}$ & Intronic & 9.7 & 72 \\
Intron 12 & ${ }^{1678-9} \mathrm{DEL} \mathrm{T}$ & Intronic & 11.1 & 106 \\
Exon 13 & ${ }^{1684} \mathrm{~T} / \mathrm{C}$ & Silent & 8.3 & 106 \\
Exon 13 & ${ }^{1704} \mathrm{C} / \mathrm{T}$ & Silent & 2.8 & 59 \\
Exon 16 & ${ }^{2012} \mathrm{G} / \mathrm{T}$ & Gly671Val & 2.8 & 43 \\
Intron 20 & ${ }^{2736-36} \mathrm{~T} / \mathrm{C}$ & Intronic & 2.8 & 132 \\
Intron 20 & ${ }^{2736-18} \mathrm{CC} / \mathrm{TT}$ & Intronic & 2.8 & 132 \\
Intron 20 & ${ }^{2736-6} \mathrm{~T} / \mathrm{C}$ & Intronic & 2.8 & 132 \\
Intron 21 & ${ }^{2871+17} \mathrm{G} / \mathrm{A}$ & Intronic & 1.4 & 132 \\
Intron 26 & ${ }^{3819+7} \mathrm{G} / \mathrm{A}$ & Intronic & 1.4 & 124 \\
Exon 28 & ${ }^{4002} \mathrm{G} / \mathrm{A}$ & Silent & 2.8 & 95 \\
Intron 30 & ${ }^{4487+5} \mathrm{~A} / \mathrm{T}$ & Intronic & 2.8 & 137 \\
Intron 30 & ${ }^{4487+18} \mathrm{~A} / \mathrm{G}$ & Intronic & 1.4 & 142 \\
Intron 30 & ${ }^{4487+28} \mathrm{C} / \mathrm{G}$ & Intronic & 2.8 & 137
\end{tabular}

Densitometrical analysis was performed with TINA software (Raytest, Straubenhardt, Germany), average relative $M R P 1$ expression was set as $100 \%$

FRE, allelic frequency in \%; EXP, expression level; SNP, singlenucleotide polymorphism

${ }^{\mathrm{a}}$ The average expression level of all samples was $100 \pm 55$

${ }^{\mathrm{b}}$ Recently described by Ito et al. $2001 \mathrm{~b}$ erozygous mutation was detected in exon 10 causing the exchange of an arginine for a serine $(\mathrm{AGG} \rightarrow \mathrm{AGT})$, and two individuals were found to be heterozygous for a glycine to valine (GGT $\rightarrow$ GTT) exchange in exon 16, which is located only six amino acids upstream from the Walker A motif in the first nucleotide binding domain (NBD1) (sequencing data in Figure 1). This glycine is highly conserved in human MRPs as well as in P-glycoprotein 1 and 3 (MDRs 1 and 3) and other human ABC-transporters (Figure 2).

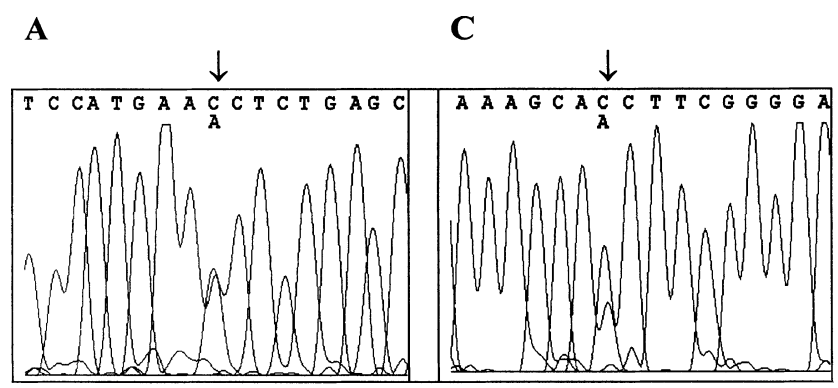

B

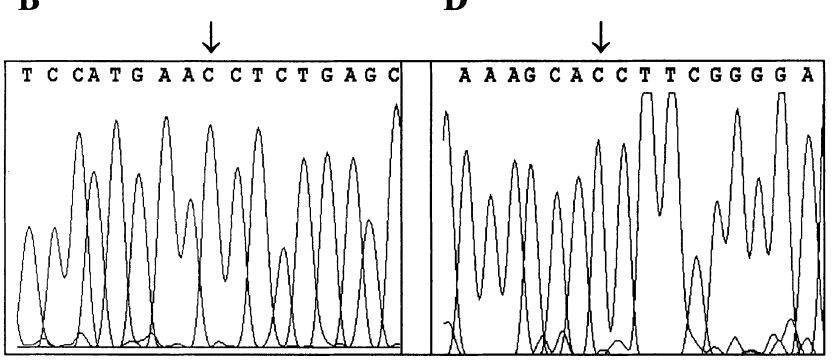

Fig. 1A-D. Multidrug resistance protein $1(M R P 1)$ exons 10 and 16: partial (reverse) sequences of (A) individual 11 (exon $10{ }^{1299} \mathrm{G}(\mathrm{C}) \rightarrow$ $\mathrm{T}(\mathrm{A})$ heterozygous); (B) individual 35 (exon 10 wild-type); (C) individual 31 (exon $16^{2012} \mathrm{G}(\mathrm{C}) \rightarrow \mathrm{T}(\mathrm{A})$ heterozygous), and (D) individual 22 (exon 16 wild-type)

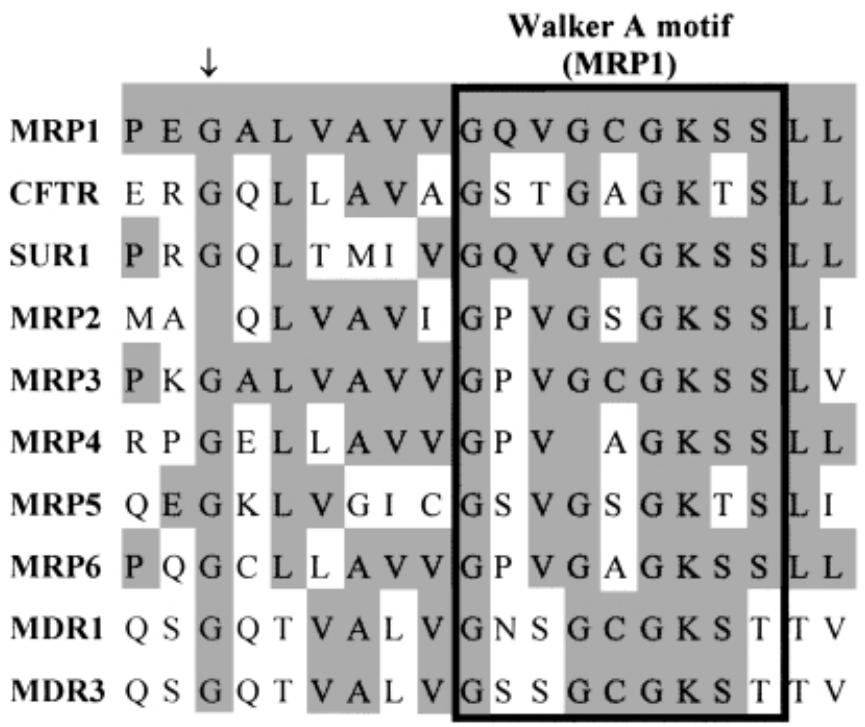

Fig. 2. Alignment of the partial first nucleotide binding domain (NBD1) sequence in MRP1 and related human ATP-binding cassette $(\mathrm{ABC})$-transporters showing the high conservation of Gly ${ }^{671}$ (arrow) 
RNA was also isolated from peripheral lymphocytes. Since MRP1 is expressed in normal peripheral T- and Blymphocytes at a similar basal level (Abbaszadegan et al. 1994), we used the total lymphocyte fraction in our investigations. Relative MRP1 mRNA amounts were determined with semiquantitative RT-PCR, and expression levels were analyzed densitometrically. Densities were calculated in arbitrary units relative to the corresponding $G A P D H$ signal.

The average expression level was set as $100 \%$. The standard deviation of $55.0 \%$ indicated a quite high individual variability of MRP1 expression. Subsequently, the expression levels of the different genotypes were determined and compared with the average expression level (Table 2). Some mutations seemed to correlate with a lower expression of MRP1. These mutations include heterozygous silent mutations in exon 8 and 13 and one heterozygous mutation in exon 16 that could alter the amino acid sequence
(G671V). The number of samples for each genotype can be calculated from the frequency and the total number of individuals (36) used in this study. The numbers were too low to provide a reasonable statistical analysis.

These results, together with the localization of G671V close to the first ATP-binding site and the highly conserved nature of $\mathrm{Gly}^{671}$ among ABC proteins (Figure 2) prompted us to analyze the functional importance of this amino acid. This was accomplished by introducing the G671V substitution into the pcDNA3.1(-)wt-MRP1 $1_{\mathrm{K}}$ expression vector by site-directed mutagenesis, followed by a transient transfection of the construct into HEKSV293T cells. Control transfections with an empty vector and the wild-type construct served as negative and positive controls, respectively. Membrane vesicles were prepared and the protein expression levels were determined by immunoblot and/or dot blot analysis (Figures 3A and 4A). The ATP-dependent uptake
A
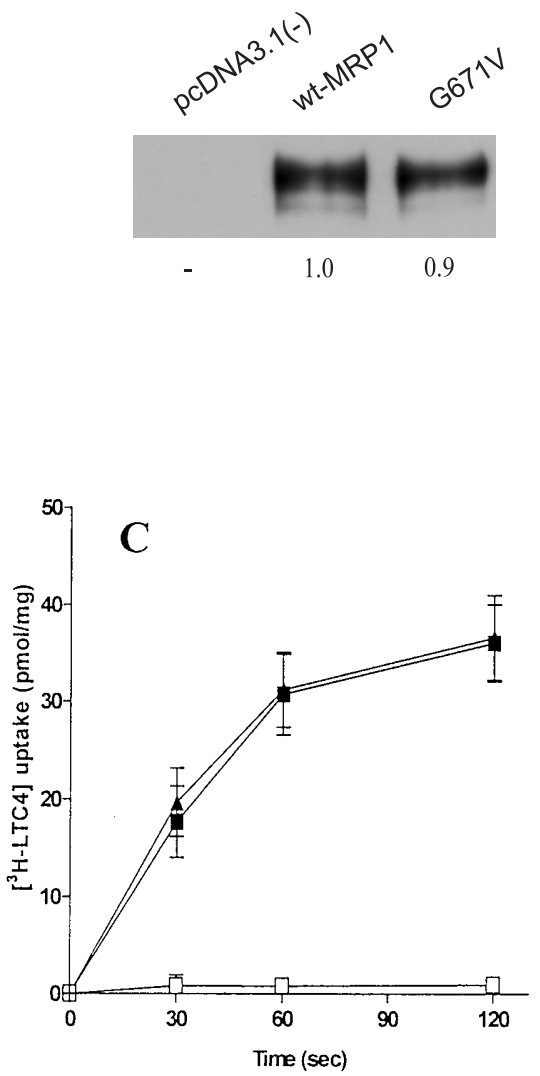
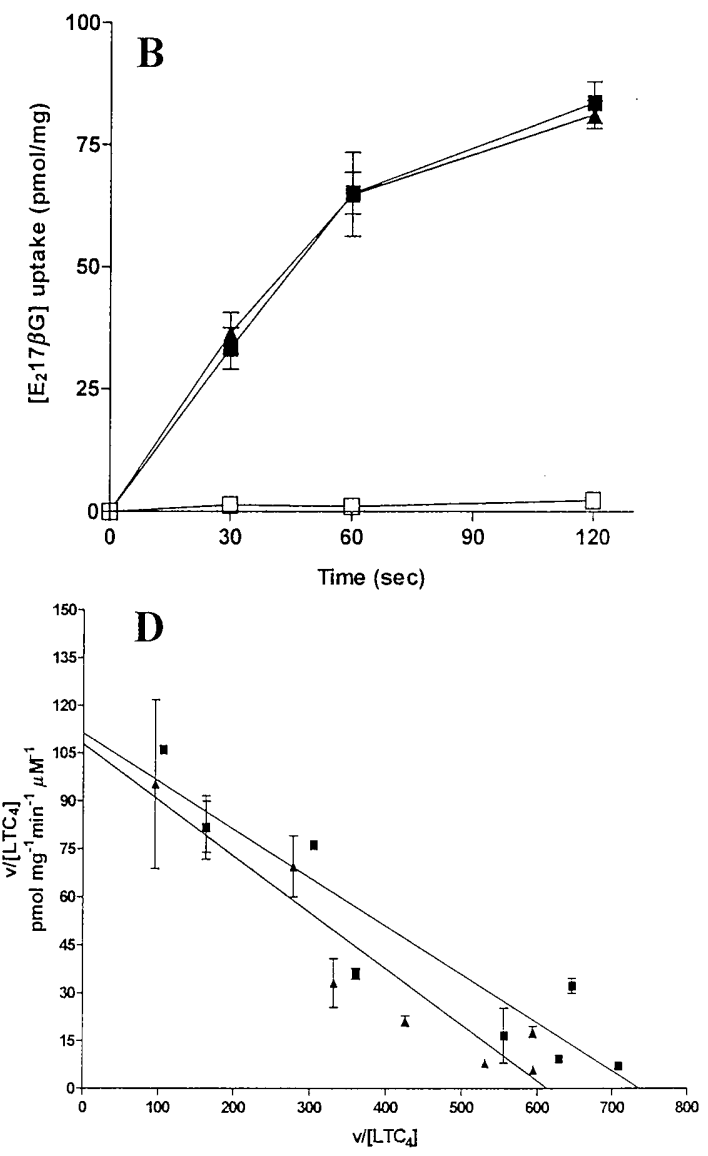

Fig. 3A-D. Transport activity of wild-type and mutant G671V-MRP1 in transiently transfected human embryonic kidney (HEKSV293T) cells. A Vesicles protein expression levels of $p c D N A 3.1(-)$ as control, pcDNA3.1(-)wt-MRP1k ( $w t-M R P k-1)$, and pcDNA3.1(-)-MRPk-1G671V $(G 671 \mathrm{~V})$ were determined by immunoblotting with the MRP1specific murine Mab QCRL-1. The numbers below the blot refer to the relative protein expression levels. $\mathbf{B}$ Time course of $\mathrm{E}_{2} 17 \beta \mathrm{G}$ uptake in membrane vesicles prepared from HEKSV293T cells transiently transfected with wild-type MRP1 (wt-MRPk-1, solid square), mutant (G671V-MRPk-1, triangle), and empty control (pcDNA3.1(-), open square) cDNA expression vectors. Results shown are means ( $\pm \mathrm{SD}$ ) of triplicate determinations in a single experiment. Similar results were found in two additional independent experiments. $\mathbf{C}$ Time course of $\mathrm{LTC}_{4}$ uptake in membrane vesicles prepared from HEKSV293T cells transiently transfected with wild-type MRP1 (wt-MRPk-1, solid square), mutant (G671V-MRPk-1, triangle), and empty control (pcDNA3.1(-), open square) cDNA expression vectors. Results shown are means $( \pm \mathrm{SD})$ of triplicate determinations in a single experiment. Similar results were found in two additional independent experiments. D Determination of $\mathrm{Km}$ and Vmax for ATP-dependent uptake of $\left[{ }^{3} \mathrm{H}\right] \mathrm{LTC}_{4}$ in membrane vesicles from transiently transfected HEKSV293T cells (wt-MRPk-1, solid square; G671V-MRPk-1, triangle). Uptake was terminated after $45 \mathrm{~s}$ at various substrate concentrations $(0.01-1 \mu \mathrm{M})$ as indicated. Kinetic parameters were subsequently determined from regression analysis of the EadieHofstee transformation of the data. Results are means ( \pm range or SD) of duplicate or triplicate determinations at each substrate concentration in a single experiment 
Fig. 4A,B. ATP-dependent uptake of estrone sulfate in membrane vesicles from transiently transfected HEKSV293T cells in the presence or absence of glutathione (GSH). A Dot blots of membrane vesicles prepared from transiently transfected HEKSV293T cells as described in Figure 3A. B ATP-dependent estrone sulfate uptake in the presence (solid square) and absence (open square) of GSH. Results shown are means $( \pm \mathrm{SD})$ of triplicate determinations in a single experiment
A

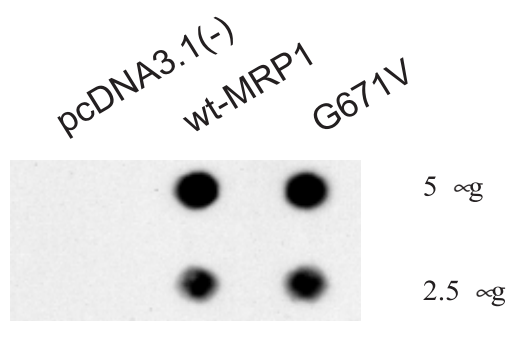

B

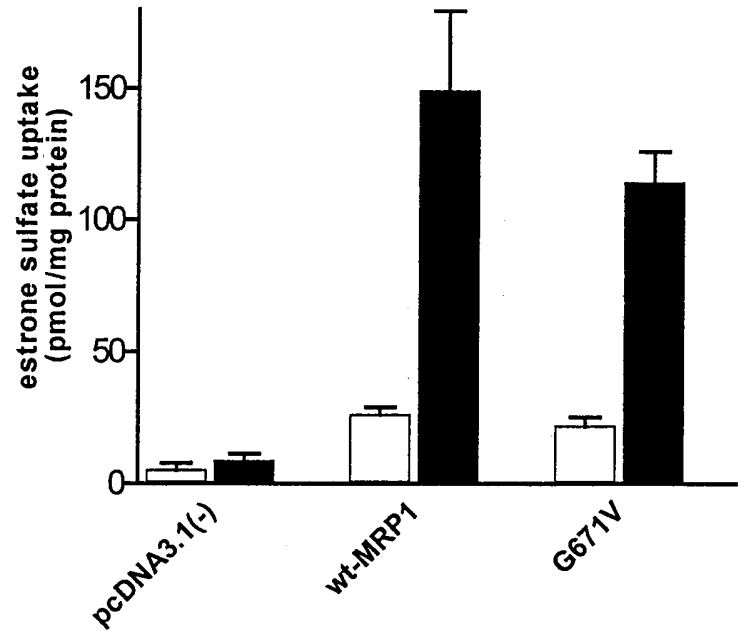

was determined by subtraction of vesicle-associated radioactivity in the presence of $4 \mathrm{mM}$ AMP from values obtained at comparable time points with $4 \mathrm{mM}$ ATP. For the $\left[{ }^{3} \mathrm{H}\right] \mathrm{LTC}_{4}$ and $\left[{ }^{3} \mathrm{H}\right] \mathrm{E}_{2} 17 \beta \mathrm{G}$ transport experiments shown in Figures $3 \mathrm{~B}$ and $\mathrm{C}$, the levels of uptake by G671V-MRP1 were comparable to wild-type MRP1. A reduced-function construct was also included (data not shown) that exhibited significantly reduced substrate transport (publication in preparation).

Our findings were supported by Eadie-Hofstee transformation (Figure 3D) of the data obtained from a ATPdependent $\left[{ }^{3} \mathrm{H}\right] \mathrm{LTC}_{4}$ uptake experiment with various substrate concentrations, which yielded similar Km (175.8 and $151.0 \mathrm{nM}$, respectively) and $\operatorname{Vmax}(107.9$ and $111.3 \mathrm{pmol} / \mathrm{mg} / \mathrm{min}$, respectively) values for G671V-MRP1 and wild-type MRP1, respectively.

We also measured ATP-dependent $\left[{ }^{3} \mathrm{H}\right]$ estrone sulfate uptake in the presence and absence of GSH (Figure 4). In accordance with previous findings, both wild-type MRP1 and G671V exhibited a markedly enhanced uptake of $\left[{ }^{3} \mathrm{H}\right]$ estrone sulfate in the presence of GSH (Qian et al. 2001). Uptake for the mutant MRP1 was again comparable to wild-type MRP1. Thus, the G671V mutant showed a phenotype similar to wild-type MRP1 (Figures 3 and 4) in all transport assays performed.

\section{Discussion}

In this study, we identified several mutations in the human MRP1 gene by analysis of blood samples by PCR-SSCP. Although some of the intronic mutations we detected are located close to exon-intron boundaries and the branch site, we have obtained no evidence that they influence gene expression or cause incorrect splicing. Further experiments that include functional analysis, Western blots, and RNA length analysis of certain regions are necessary to clarify the putative relevance of these mutations. Two mutations are predicted to cause amino acid substitutions. They are located in the second transmembrane spanning domain (R433S) and in the vicinity of the first ATP-binding site (G671V). G671V is located only six amino acids upstream from the conserved Walker A motif in the nucleotide binding domain, and previous studies have shown that mutations in and near the Walker A motifs can cause a decrease in transport activity (Gao et al. 2000; Szakacs et al. 2000; Ramjeesingh et al. 1999).

Interestingly, mRNA analysis demonstrated that the individuals bearing the mutation in exon 16 express $M R P 1$ mRNA at a relatively low level. One possible explanation for this observation is that the mutation might cause a decrease in mRNA stability. Another possible explanation is that the mutation might be linked to a (still unknown) mutation in the regulatory region of the gene that disturbs the transcription process.

In addition, two other (silent) exon mutations seem to correlate with a lower MRP1 mRNA expression, possibly also due to a decrease in mRNA stability. However, the allelic frequency of the mutations that correlate with low MRP1 expression is obviously quite low. Therefore, future studies with larger collections of samples are required in order to determine the influence of these mutations on $M R P 1 \mathrm{mRNA}$ expression.

Several individuals expressing very low $M R P 1 \mathrm{mRNA}$ levels were not found to bear any mutations in the $M R P 1$ gene, including the region corresponding to the proximal promoter. This suggests other mechanisms and/or mutations to be additionally involved in regulating MRP1 expression. For example, mutations in genes involved in signal transduction pathways, regulating MRP1 expression such as Sp1 (Zhu and Center 1996) or p53 (Sullivan et al. 
2000; Lin-Lee et al. 2001) — and/or mutations in promoter/ enhancer sequences located far upstream might also influence $M R P 1$ basal expression.

Of all the mutations detected in the present study, we specifically examined the functional consequences of the G671V substitution for three reasons: (1) the reduced mRNA expression of the affected individuals; (2) the high conservation of $\mathrm{Gly}^{671}$ in several subfamily C ABCtransporters; and (3) the location of the exchange position near the essential Walker A motif of NBD1.

However, our results indicate that this substitution has no detectable influence on the $\mathrm{E}_{2} 17 \beta \mathrm{G}$, estrone sulfate, and $\mathrm{LTC}_{4}$ transport activities of MRP1. Moreover, kinetic analysis of $\mathrm{LTC}_{4}$ transport demonstrated no differences in substrate affinity $(\mathrm{Km})$ or uptake velocity (Vmax).

Although organic anion transport appears unaffected, it is possible the G671V substitution could affect drug resistance, since the two properties are not always linked. Thus, it has recently been reported using recombinant MRP1 that substituting of a nonconserved glutamate at position 1089 dramatically affected drug resistance without affecting the kinetics of $\mathrm{LTC}_{4^{-}}, \mathrm{E}_{2} 17 \beta \mathrm{G}$-, and $\mathrm{GSH}$-stimulated estrone sulfate transports (Zhang et al. 2001; Qian et al. 2001).

In a separate study, substitution of a conserved tryptophan at position 1246 left $\mathrm{LTC}_{4}$ and verapamil stimulated GSH transport and resistance towards heavy metal oxyanions intact, but eliminated the ability of MRP1 to confer drug resistance towards anthracyclines, vincristine, and VP-16 and to transport $\mathrm{E}_{2} 17 \beta \mathrm{G}$ (Ito et al. 2001a).

Thus, it remains possible that the G617V mutation affects only the transport properties of certain MRP1 substrates. To test this possibility, it will be necessary to establish stably transfected cell lines so that the chemosensitivity and drug accumulation properties of this mutant can be investigated.

In summary, we identified several point mutations in the MRP1 gene and characterized for the first time a naturally occurring single-nucleotide polymorphism predicted to result in an amino acid substitution in this gene. Despite the fact that it was a highly conserved residue near the Walker A motif and associated with reduced levels of mRNA, this mutant showed no differences in organic anion transport activities compared to wild-type MRP1.

Acknowledgments The authors thank Dr. J. Fischer (University of Kaiserslautern, Medical Service) for the blood sampling. We also thank Elaine Leslie and Curtis Oleschuk for advice on transport experiments, Kathy Sparks for technical assistance, and Derek Schulze for performing flow cytometry.

This study was supported by the Ministry for Education and Research (BMBF), "Leitprojekt: Diagnose und Therapie mit Mitteln der Molekularen Medizin," Bonn, Germany, and by the Canadian Institutes of Health Research (MOP-10519).

\section{References}

Abbaszadegan MR, Futscher BW, Klimecki WT, List A, Dalton WS (1994) Analysis of multidrug resistance-associated protein (MRP) messenger RNA in normal and malignant hematopoietic cells. Cancer Res 54:4676-4679
Chomczynski P, Sacchi N (1987) Single-step method of RNA isolation by acid guanidinium thiocyanate-phenol-chloroform extraction. Anal Biochem 162:156-159

Cole SPC, Bhardwaj G, Gerlach JH, Mackie JE, Grant CE, Almquist KC, Stewart AJ, Kurz EU, Duncan AMV, Deeley RG (1992) Overexpression of a transporter gene in a multidrug-resistant human lung cancer cell line. Science 258:1650-1654

Cole SPC, Sparks KE, Fraser K, Loe DW, Grant CE, Wilson GM, Deeley RG (1994) Pharmacological characterization of multidrug resistant MRP-transfected human tumor cells. Cancer Res 54:59025910

Conrad S, Viertelhaus A, Orzechowski A, Hoogstraate J, Gjellan K, Schrenk D, Kauffmann HM (2001) Sequencing and tissue distribution of the canine MRP2 gene compared with MRP1 and MDR1. Toxicology 156:81-91

Evers R, Cnubben NH, Wijnholds J, van Deemter L, van Bladeren PJ, Borst P (1997) Transport of glutathione prostaglandin A conjugates by the multidrug resistance protein 1. FEBS Lett 419(1):112-116

Gao M, Cui HR, Koe DW, Grant CE, Almquist KC, Cole SPC, Deeley RG (2000) Comparison of the functional characteristics of the nucleotide binding domains of multidrug resistance protein 1 . J Biol Chem 275:13098-13108

Grant CE, Kurz EU, Cole SPC, Deeley RG (1997) Analysis of the intron-exon organization of the human multidrug resistance protein gene (MRP) and alternative splicing of its mRNA. Genomics 45(2):368-378

Hipfner DR, Almquist KC, Stride BD, Deeley RG, Cole SPC (1996) Location of a protease-hypersensitive region in the multidrug resistance protein (MRP) by mapping of the epitope of MRP-specific monoclonal antibody QCRL-1. Cancer Res 56(14):3307-3314

Hipfner DR, Deeley RG, Cole SPC (1999a) Structural, mechanistic and clinical aspects of MRP1. Biochim Biophys Acta 1461:359376

Hipfner DR, Mao Q, Qiu W, Leslie EM, Gao M, Deeley RG, Cole SPC (1999b) Monoclonal antibodies that inhibit the transport function of the $190-\mathrm{kDa}$ multidrug resistance protein, MRP. Localization of their epitopes to the nucleotide-binding domains of the protein. J Biol Chem 274(22):15420-15426

Hopper E, Belinsky MG, Zeng H, Tosolini A, Testa JR, Kruh GD (2001) Analysis of the structure and expression pattern of MRP7 (ABCC10), a new member of the MRP subfamily. Cancer Lett 162(2):81-191

Ito K, Olsen SL, Qiu W, Deeley RG, Cole SPC (2001a) Mutation of a single conserved tryptophan in multidrug resistance protein 1 (MRP1/ABCC1) results in loss of drug resistance and selective loss of organic anion transport. J Biol Chem 276(19):15616-15624

Ito S, Ieiri I, Tanabe M, Suzuki A, Higuchi S, Otsubo K (2001b) Polymorphism of the ABC transporter genes, MDR1, MRP1 and MRP2/cMOAT, in healthy Japanese subjects. Pharmacogenetics 11(2):175-184

Jedlitschky G, Leier I, Buchholz U, Barnouin K, Kurz G, Keppler D (1996) Transport of glutathione, glucuronate, and sulfate conjugates by the MRP gene-encoded conjugate export pump. Cancer Res 56(5):988-994

Kauffmann H-M, Gant TW, Keppler D, Schrenk D (1998) Induction of hepatic mrp2 (cmrp/cmoat) gene expression in nonhuman primates treated with rifampicin or tamoxifen. Arch Toxicol 72:763-768

König J, Nies AT, Cue Y, Keppler D (1999) Conjugate export pumps of the multidrug resistance protein (MRP) family: localization, substrate specificity, and MRP2-mediated drug resistance. Biochim Biophys Acta 1461(2):377-394

Kuwano M, Toh S, Uchiumi T, Takano H, Kohno K, Wada M (1999) Multidrug resistance-associated protein subfamily transporters and drug resistance. Anticancer Drug Des 14:123-131

Leier I, Jedlitschky G, Buchholz U, Cole SPC, Deeley RG, Keppler D (1994) The MRP-gene encodes an ATP-dependent export pump for leukotriene $\mathrm{C}_{4}$ and structurally related conjugates. J Biol Chem 269:27807-27810

Leier I, Jedlitschky G, Buchholz U, Center M, Cole SPC, Deeley RG, Keppler D (1996) ATP-dependent glutathione disulphide transport mediated by the MRP gene-encoded conjugate export pump. Biochem J 314:433-437

Lin-Lee YC, Tatebe S, Savaraj N, Ishikawa T, Tien Kuo M (2001) Differential sensitivities of the MRP gene family and gammaglutamylcysteine synthetase to prooxidants in human colorectal car- 
cinoma cell lines with different p53 status. Biochem Pharmacol 61(5):555-563

Loe DW, Almquist KC, Deeley RG, Cole SPC (1996a) Multidrug resistance protein (MRP)-mediated transport of leukotriene $\mathrm{C} 4$ and chemotherapeutic agents in membrane vesicles. Demonstration of glutathione-dependent vincristine transport. J Biol Chem 271(16):9675-9682

Loe DW, Almquist KC, Cole SPC, Deeley RG (1996b) ATPdependent 17 beta-estradiol 17-(beta-D-glucuronide) transport by multidrug resistance protein (MRP). Inhibition by cholestatic steroids. J Biol Chem 271(16):9683-9689

Mao Q, Deeley RG, Cole SPC (2000) Functional reconstitution of substrate transport by purified multidrug resistance protein MRP1(ABCC1) in phospholipid vesicles. J Biol Chem 275(44):34166-34172

Qian YM, Song WC, Cui H, Cole SPC, Deeley RG (2001) Glutathione stimulates sulfated estrogen transport by multidrug resistance protein 1. J Biol Chem 276(9):6404-6411

Ramjeesingh M, Li C, Garami E, Huan LJ, Galley K, Wang Y, Bear CE (1999) Walker mutations reveal loose relationship between catalytic and channel-gating activities of purified CFTR (cystic fibrosis transmembrane conductance regulator). Biochemistry 38(5):14631468

Renes J, de Vries EE, Hooiveld GJ, Krikken I, Jansen PL, Muller M (2000) Multidrug resistance protein MRP1 protects against the tox- icity of the major lipid peroxidation product 4-hydroxynonenal. Biochem J 350:555-561

Sullivan GF, Yang JM, Vassil A, Yang J, Bash-Babula J, Hait WN (2000) Regulation of expression of the multidrug resistance protein MRP1 by $\mathrm{p} 53$ in human prostate cancer cells. J Clin Invest 105(9):1261-1267

Szakacs G, Ozvegy C, Bakos E, Sarkadi B, Varadi A (2000) Transitionstate formation in ATPase-negative mutants of human MDR1 protein. Biochem Biophys Res Commun 276(3):1314-1319

Wijnholds J, Evers R, van Leusden MR, Mol CA, Zaman GJ, Mayer U, Beijnen JH, van der Valk M, Krimpenfort P, Borst P (1997) Increased sensitivity to anticancer drugs and decreased inflammatory response in mice lacking the multidrug resistanceassociated protein. Nat Med 3(11):1275-1279

Zaman GJR, Flens MJ, van Leusden MR, de Haas M, Mülder HS, Lankelma J, Pinedo HM, Scheper RJ, Baas F, Broxterman HJ, Borst $\mathrm{P}$ (1994) The human multidrug resistance-associated protein MRP is a plasma membrane drug-efflux pump. Proc Natl Acad Sci U S A 91:8822-8826

Zhang DW, Cole SPC, Deeley RG (2001) Identification of an amino acid residue in multidrug resistance protein 1 critical for conferring resistance to anthracyclines. J Biol Chem 276(16):13231-13239

Zhu Q, Center MS (1996) Evidence that SP1 modulates transcriptional activity of the multidrug resistance-associated protein gene. DNA Cell Biol 15:105-111 